\title{
ARTICLE
}

\section{Multi-method (XRF, FTIR, TGA) analysis of ancient bricks from Karabalgasun: A preliminary study}

\author{
$\underline{\text { Saran Solongo }}^{1 *}$, Christina Franken ${ }^{2}$, Saran Tengis ${ }^{1,3}$ \\ Erdenebat Ulambayar $^{4}$ and Tumur-Ochir Batbayr ${ }^{5}$ \\ ${ }^{I}$ Institute of Physics and Technology, Mongolian Academy of Sciences \\ Ulaanbaatar, Mongolia \\ ${ }^{2}$ KAAK, Deutsches Archäologisches Institut, Bonn, Germany \\ ${ }^{3}$ Department of Physics, University of Turin, Turin, Italy \\ ${ }^{4}$ Department of Anthropology and Archaeology, National University of Mongolia \\ Ulaanbaatar, Mongolia \\ ${ }^{5}$ Institute of Archaeology, Mongolian Academy of Sciences, Ulaanbaatar, Mongolia
}

Abstract: Ancient ceramic artefacts attracted the attention of scientists as being a chronological indicator within the archaeological context; however, they can also provide information about the tech-nology and provenance. A series of brick samples from an ancient nomadic town at Karabalgasun (Mongolia) have been analyzed using X-ray fluorescence (XRF) spectroscopy, Fourier transform infrared spectroscopy (FTIR) and thermogravimetric (TG) analysis in order to obtain information on the performance of the kilns used and on the technological skills of ancient pot-ters.

Keywords: RHX dating; clay ceramic; FTIR; XRF; TGA; mass-gain; mass-loss;

\section{INTRODUCTION}

Ceramic architectural materials, such as bricks and tiles, provide valuable information about their history; the analysis of clay brick unearthed in archaeological sites reveals information about the place and date of manufacture, provenance and production technology, which helps to understand the socio-economic and political aspects of ancient societies [1].
Karabalgasun or Ordu Balik (740-840 AD) lies on the left bank of Orkhon River, approximately $35 \mathrm{~km}$ north-northwest of the former Mongolian capital of Karakorum [2]. As one of the ancient sites in Mongolia, the early Uighur capital of Karabalgasun was the largest medieval city in Eastern Central Asia. The size of Karabalgasun would measure at least 32 square kilometers on its surface.

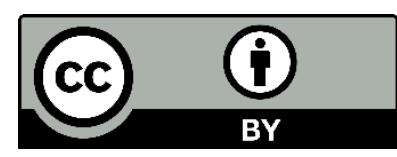

The Author(s). 2020 Open access This article is distributed under the terms of the Creative Commons Attribution 4.0 International License (https://creativecommons.org/licenses/by/4.0/), which permits unrestricted use, distribution, and reproduction in any medium, provided you give appropriate credit to the original author(s) and the source, provide a link to the Creative Commons license, and indicate if changes were made. 
The archaeological work concentrated at first on questions of the development of the city, as well as on the research on the internal division and the function of different urban districts.

Among the most abundant artefacts retrieved from these sites are fired bricks, which are up to $32.2 \mathrm{~mm} \times 26.5 \mathrm{~mm} \times 5.3 \mathrm{~mm}$ in measurement. The effects of firing on a given raw clay have been subject to numerous analyses, most of which focus on the mineralogical changes. Archaeometry is widely used for characterizing the thermal, mineralogical, spectroscopic aspects of ancient artefacts [3],[4], especially Fourier transform infrared (FTIR) spectroscopy has proved to be an optical technique that can be used for characterizing a wide range of minerals

\section{MATERIALS AND METHODS}

\section{Sampling and analytical methods}

Site and samples: Karabalgasun has been studied since the late 19th century and W.Radloff of the Russian Orkhon expedition drew the first topographical map of the city in 1891 [9]. In 2007, the archaeological survey by the Mongolian-German Orkhon expedition (MONDOrEX) of the Archaeological Institute of the Mongolian Academy of Sciences (MAS) and the German Archaeological Institute (KAAK) Bonn, Germany performed an airborne laserscan and created a topographical map of the entire site [10]. The areas excavated
[5],[6],[7]. The firing temperatures of ancient ceramics are of interest because they provide information on the performance of the kilns used in their manufacture and on the technological skills [8]. The assessment can be obtained by combining mineral identification and thermal analysis techniques.

The aim of this work, which is the first archaeometric study made on bricks unearthed in Karabalgasun, is to undertake a multianalytical study of bricks using the spectroscopic (XRF, FTIR) and thermoanalytical (TGA) techniques to provide information about the mineralogical composition and the firing temperature of production technology of ancient bricks.

by the German-Mongolian project are Manichaean temple area (HB1), palace or temple complex (HB2), building within the inner city (HB3) and site outside the city (HB4), which are shown in Figure 1. Architectural ceramics, such as wall bricks and pavement bricks, were unearthed from two different sites HB2 and HB4 in Karabalgasun. The bricks had different color, ranging from grey to red brown, and also the sizes were different, around 32.2 $\mathrm{mmx} 26.5 \mathrm{~mm}$, but all of them had an identical thickness around 5 to $6 \mathrm{~mm}$ (Figure 1, Table 1).

Table 1. Samples studied in this work

\begin{tabular}{|l|l|l|}
\hline Area \# & Sample description & \\
\hline HB2 site & HB-2;H-1, 2017 & Brick, grey, $18.5 \mathrm{~mm} \times 9.9 \mathrm{~mm} \times 5.3 \mathrm{~mm}$ \\
\cline { 2 - 3 } & $H B-2 ; H-2,2017$ & Brick, brown, $15.5 \mathrm{~mm} \times 10 \mathrm{~mm} \times 5.5 \mathrm{~mm}$ \\
\cline { 2 - 3 } & $H B-2 ; H-3,2017$ & $\begin{array}{l}\text { PC77-86,96;87,97/72-B9073: Brick, red brown, } \\
32.2 \mathrm{~mm} \times 26.5 \mathrm{~mm} \times 5.3 \mathrm{~mm}\end{array}$ \\
\hline \multirow{2}{*}{ HB4 site } & $H B-4-1,2017,($ ND68-81)/(13-B9503) & Brick, brown, size: $19.5 \mathrm{~mm} \times 15.5 \mathrm{~mm} \times 5.5 \mathrm{~mm}$ \\
\cline { 2 - 3 } & $H B-4-2,2017,(\mathrm{ND} 67-36) /(14-B 9506)$ & Brick O15, dark grey, $14.5 \mathrm{~mm} \times 9.8 \mathrm{~mm} \times 6 \mathrm{~mm}$ \\
\hline
\end{tabular}



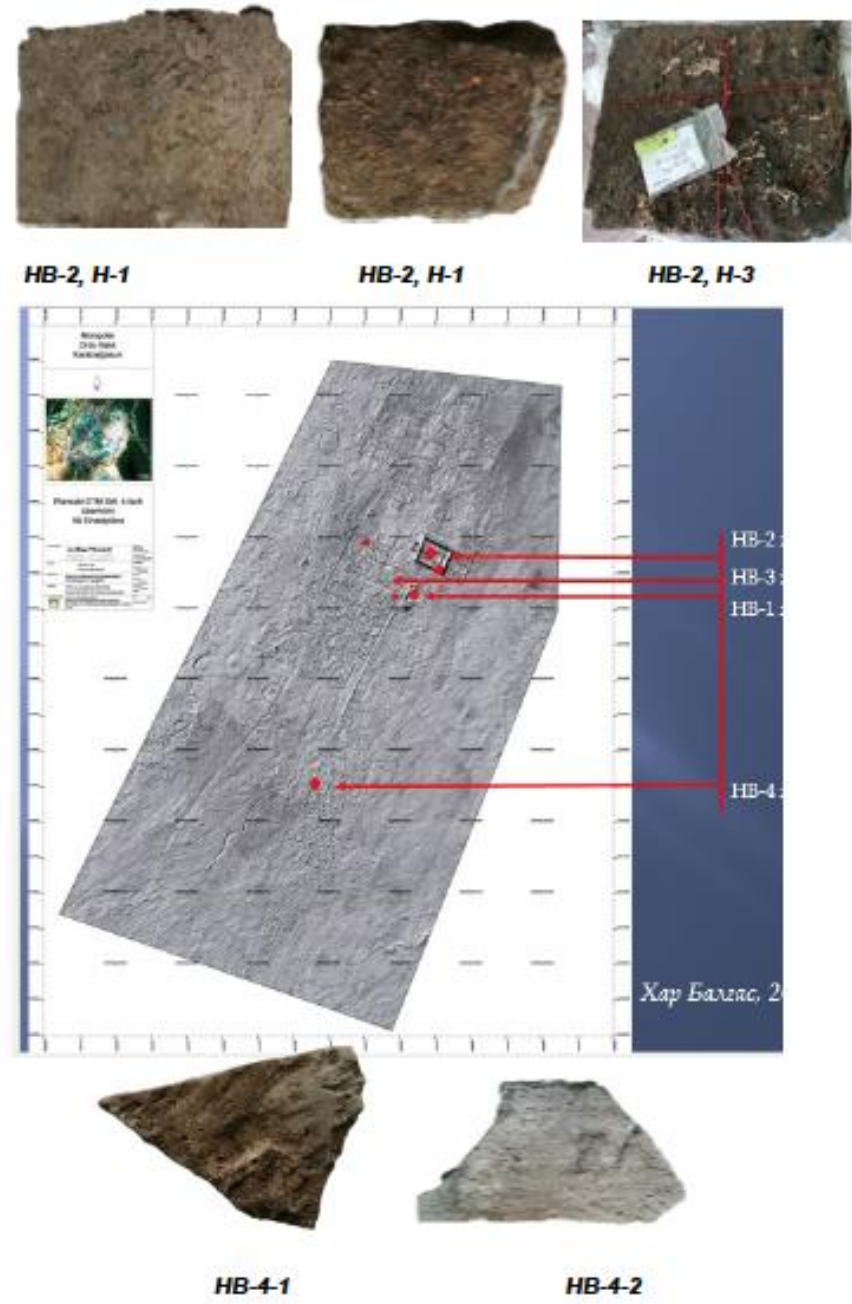

Figure 1. Wall bricks and pavement bricks unearthed from HB2 and HB4 sites in Karabalgasun

$\mathrm{XRF}$ is commonly used to identify the chemical/elemental composition of clay ceramics. It has been criticized for the possibility of producing biased data if, for example, unprepared sample of coarse-ware ceramics are analyzed due to matrix inhomogeneity [3]. However, its application on finely pulverized samples from clay brick samples in the present study keeps this problem minimized. The powdered samples were analyzed using a AXIOS -wavelength dispersive spectrometer PAN Analytical with a Rh excitation source (Geological Laboratory).

FTIR provides information on both the organic and inorganic fraction of clays. The FTIR spectra were recorded in the mid-infrared region (400-4000 $\left.\mathrm{cm}^{-1}\right)$ using a Prestige-21 Shimadzu (Japan) spectrometer with a pyro electric detector operating with a resolution of $2 \mathrm{~cm}^{-1}$ in transmittance mode. The sample preparation process consisted of grinding the sample to obtain fine powder, which was then mixed with $\mathrm{KBr}$ powder.

TG provides information in three steps of mass loss due to heating: dehydration, dehydroxylation, and calcite decomposition. Finely grounded powder samples were heated at room temperature to $900^{\circ} \mathrm{C}$ in a nitrogen atmosphere at a heating rate of $10^{\circ} \mathrm{C} / \mathrm{min}$ for TGA. Thermal analyses were performed by a TGA 2100D instrument and the corresponding software was used in the assessment of the results.

\section{Firing temperature of ancient ceramics}

Estimation of ceramic firing temperature has been used in a number of studies focused on the reconstruction of ceramic technology during manufacture [11]. Firing clay objects is an irreversible process, which produces ceramic materials, characterized by new chemical-mineralogical composition and 
different physical and microstructural properties. Estimating this parameter generally relies upon changes in the mineral composition, as determined by X-ray diffraction of the ceramics [12], or by Fourier transform spectroscopy [5], as temperature in-creases. These changes may include the disappearance of minerals, the crystallization and the formation of new mineral phases.

The firing temperature is also estimated using the data obtained from thermal gravimetric measurements on the ceramics, the method that allows one to separate the mass loss of a clay mineral due to dehydration and dehydroxylation, because these two processes occur in different temperature intervals. TGA analysis is then used under the assumption when a ce-ramic material is analysed by a second heating (e.g. in the laboratory), exothermic reactions are supposed to occur at temperatures higher than the temperature of the first heating due to firing [13]. The visualization of the results of thermogravimetric measurements of ancient ce-ramics and their

\section{RESULTS AND DISCUSSION}

\section{Mineralogical composition using X-ray fluorescence and FTIR}

Two representative samples from two different sites were characterized by X-ray fluorescence. As can be seen from Table 2, the presence of quartz $\left(\mathrm{SiO}_{2}\right)$ as the main application to the interpretation of potsherds was proposed recently by [14] as a mass-loss diagram to access mild or strong firing conditions.

In addition, there are also other approaches that involve the use of thermal expansion and dilation of regularly shaped samples of ceramics [8]; measuring the magnetic susceptibil-ity on a step-wise re-fired sample; use of electron paramagnetic resonance (EPR) to follow spectral changes in $\mathrm{Fe}^{3+}$ of $\mathrm{Mn}^{2+}$ with temperature [15].

Thermoluminescence (TL) method has also been used for the estimation of firing temperature of ceramics in addition to the dating, using optically stimulated luminescence ([16], [17], [18]). These techniques are based on atomic-level changes in the crystal structure of minerals under radiation and stimulation. Using $\mathrm{TAC}$, the intensities of $110^{\circ} \mathrm{C}$ peak of the predose sensitised quartz after annealing at temperatures from 300 to $750^{\circ} \mathrm{C}$ in $50^{\circ} \mathrm{C}$ interval steps [19] were measured.

constituent with content from $\sim 62$ to $64 \%$ was evidenced for both samples. The presence of aluminosilicates, and muscovite can be derived. Further, the presence of $\mathrm{Na}_{2} \mathrm{O}$ suggests the presence of albite (Na-feldspar) and $\mathrm{K}_{2} \mathrm{O}$ suggests the presence of K-feldspars.

Table 2. Minerals detected by XRF

\begin{tabular}{|c|c|c|c|c|c|c|c|c|c|c|c|c|c|}
\hline № & Sample ID & $\begin{array}{c}\mathbf{S i O}_{2} \\
\%\end{array}$ & $\begin{array}{c}\mathbf{T i O}_{2} \\
\%\end{array}$ & $\begin{array}{c}\mathbf{A l}_{2} \mathbf{O}_{3} \\
\%\end{array}$ & $\begin{array}{c}\sum \mathbf{F e}_{2} \mathbf{O}_{3} \\
\%\end{array}$ & $\begin{array}{c}\mathbf{C a O} \\
\%\end{array}$ & $\begin{array}{c}\mathbf{N a}_{2} \mathbf{O} \\
\%\end{array}$ & $\begin{array}{c}\mathbf{K}_{2} \mathbf{O} \\
\%\end{array}$ & $\begin{array}{c}\mathbf{A s} \\
\mathrm{ppm}\end{array}$ & $\begin{array}{c}\mathbf{C e} \\
\mathrm{Ppm}\end{array}$ & $\begin{array}{c}\mathbf{C o} \\
\mathrm{ppm}\end{array}$ & $\begin{array}{c}\mathbf{C r} \\
\mathrm{ppm}\end{array}$ & $\begin{array}{c}\mathbf{C u} \\
\mathrm{ppm}\end{array}$ \\
\hline 1 & $\begin{array}{c}\text { HB-2, H-1, 2017: } \\
\text { Brick, grey }\end{array}$ & 64.06 & 0.843 & 16.17 & 5.60 & 3.67 & 2.88 & 3.35 & 10 & 71 & 7 & 151 & 52 \\
\hline 4 & $\begin{array}{c}\text { HB-4, 2017: } \\
\text { Brick, brown }\end{array}$ & 61.79 & 0.840 & 16.21 & 5.97 & 4.50 & 2.60 & 3.17 & 20 & 94 & 9 & 98 & 22 \\
\hline
\end{tabular}

Table 2(continued). Minerals detected by XRF

\begin{tabular}{|c|c|c|c|c|c|c|c|c|c|c|c|c|c|c|}
\hline № & Sample ID & $\begin{array}{c}\mathbf{L a} \\
\mathrm{ppm}\end{array}$ & $\begin{array}{c}\mathbf{N i} \\
\text { ppm }\end{array}$ & $\begin{array}{c}\mathbf{P b} \\
\mathrm{ppm}\end{array}$ & $\begin{array}{r}\mathbf{R b} \\
\mathrm{ppm}\end{array}$ & $\begin{array}{c}\text { Sc } \\
\text { ppm }\end{array}$ & $\begin{array}{c}\mathbf{S r} \\
\mathrm{ppm}\end{array}$ & $\begin{array}{c}\text { Th } \\
\text { ppm }\end{array}$ & $\begin{array}{c}\mathbf{U} \\
\mathrm{ppm}\end{array}$ & $\begin{array}{c}\mathbf{V} \\
\mathrm{ppm}\end{array}$ & $\begin{array}{c}\text { W } \\
\text { Ppm }\end{array}$ & $\begin{array}{c}\mathbf{Y} \\
\mathrm{ppm}\end{array}$ & $\begin{array}{l}\mathbf{Z n} \\
\mathrm{ppm}\end{array}$ & $\begin{array}{r}\mathbf{Z r} \\
\mathrm{ppm}\end{array}$ \\
\hline 1 & $\begin{array}{c}\text { HB-2, H-1, 2017: } \\
\text { Brick, grey }\end{array}$ & 42 & 37 & 21 & 105 & 15 & 394 & 12 & $<5$ & 91 & $<8$ & 31 & 85 & 318 \\
\hline 4 & $\begin{array}{l}\text { HB-4, 2017: } \\
\text { Brick, brown }\end{array}$ & 32 & 35 & 25 & 110 & 12 & 414 & 15 & $<5$ & 106 & $<8$ & 29 & 92 & 252 \\
\hline
\end{tabular}


As for composition, two types of raw materials can be distinguished, i.e. noncalcareous and calcareous, based on whether $\mathrm{CaO}$ content is less or higher than $6 \%$. The Table reveals that the brick samples are noncalcareous. As concerns other metal compounds within the bricks, total iron oxides (hematite, $\mathrm{Fe}_{2} \mathrm{O}_{3}$ and magnetite, $\mathrm{Fe}_{3} \mathrm{O}_{4}$ ) content varied from 5.6 to $5.97 \%$.

FTIR spectra of bricks are shown in Fig.2; the assignments were made in correlation with other references, the slight shifting of the corresponding wave numbers is compared to other references being registered due to use of different infrared methods. In agreement with XRF results, the presence of quartz, as one of the main constituents of the bricks, is inferable by the appearance of the characteristic absorption bands situated between 1170$1140 \mathrm{~cm}^{-1} \quad(\mathrm{Si}-\mathrm{O}$ asymmetrical stretching modes), 1088-1081 $\mathrm{cm}^{-1}$ (Si-O stretching), 797 and $777 \mathrm{~cm}^{-1} \quad(\mathrm{Si}-\mathrm{O}$ symmetrical stretching modes) and at $694 \mathrm{~cm}^{-1}$ (Si-O symmetrical bending modes), respectively [5]; [20], detected in all the samples.

The broad absorption band, centered around $3400-3440 \mathrm{~cm}^{-1}$, is present in all samples $\mathrm{HB} 2$ and $\mathrm{HB}-4$ and is due to $\mathrm{O}-\mathrm{H}$ stretching mode of the dehydroxylated montmorillonite (smectite) [21]. This is always accompanied by a band around $1640 \mathrm{~cm}^{-1}$ assigned to $\mathrm{H}-\mathrm{O}-\mathrm{H}$ bending of absorbed water.
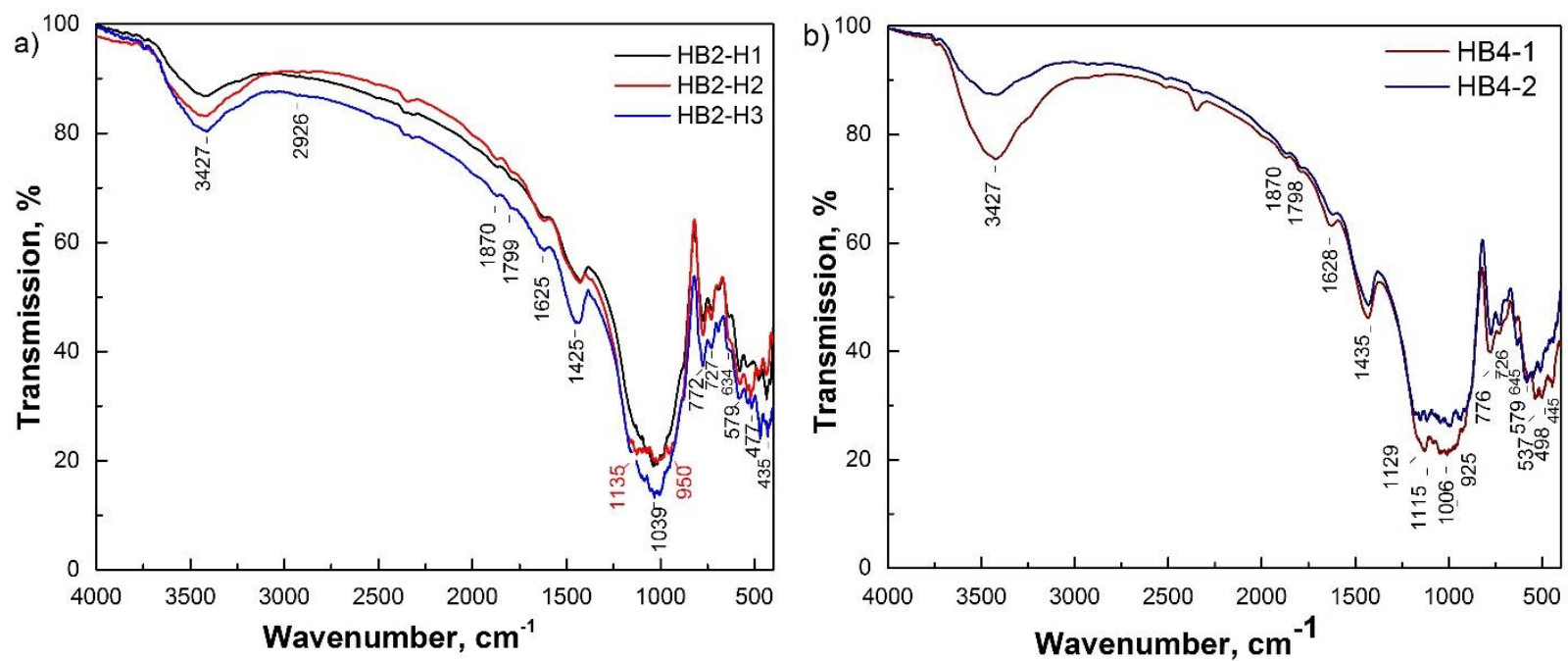

Figure 2. FTIR spectra of bricks from sites a) HB2 and b) HB4 in Karabalgasun

Feldspars were detected: the minerals albite and orthoclase can be identified by their absorption in the ranges of 1200-900, 800-700 and $650-375 \mathrm{~cm}^{-1}[21]$. The bands that can be associated with microcline (e.g. 727, 648 and $\left.534 \mathrm{~cm}^{-1}\right)$, albite (e.g.1135, $\left.927 \mathrm{~cm}^{-1}\right)$ and anorthite $\left(1131,1085,1008,920 \mathrm{~cm}^{-1}\right)$ were detected in all samples.

The presence of hematite was evidenced at 537 and $477 \mathrm{~cm}^{-1}$ and magnetite at $575-580$ $\mathrm{cm}^{-1}$ for red- colored and grey-colored bricks, respectively [22]. Iron oxides in ceramic bode, as hematite and magnetite; provide information about the atmospheric condition during firing: oxidizing and reducing atmosphere, respectively. However, the presence of hematite in ceramics served as a hint of firing at temperatures higher than $850^{\circ} \mathrm{C}$ [23].

The absorbance bands at $\sim 1795-1797$, $1425-1435 \mathrm{~cm}^{-1}$, and $726 \mathrm{~cm}^{-1}$ are to be attributed to carbonates $\left(\mathrm{CO}_{3}^{2-}\right.$ stretching and bending modes) [24], which appear in FTIR spectra, confirming that the samples probably contain calcite. Calcite can serve as a diagnostic mineral to estimate the maximum firing temperature; the presence of calcite in FTIR spectra can provide information about raw materials, technological production, and firing temperature [25]. The presence of calcite suggests the processing temperature below $900^{\circ} \mathrm{C}$, probably in the range of $850^{\circ} \mathrm{C}$ [13]. 
The mineralogical composition of bricks HB2-1 and HB2-2 is very similar and consists of quartz, feldspar, iron oxide, muscovite, montmorillonite. Sample HB2-3 has a higher content of calcite. In contrast, bricks from site HB4 show broader main absorption band.

Shoval et al.,[25] identified the shift in the Si-O stretching band to higher wave numbers between 500 and $900^{\circ} \mathrm{C}$ for kaolinite and a more upward abrupt shift for smectite. The Si-O stretching band location is steady between 600 and $700^{\circ} \mathrm{C}$ at around $1042 \mathrm{~cm}^{-1}$ but then jumps abruptly to $1090 \mathrm{~cm}^{-1}$ at $800^{\circ} \mathrm{C}$ and remains very close to this location up to $1000^{\circ} \mathrm{C}$. The presence of montmorillonite is also shown by the peaks at $1040-1049 \mathrm{~cm}^{-1}$ [6], and the presence of this band may indicate firing temperature below $900^{\circ} \mathrm{C}$ for both grey-colored

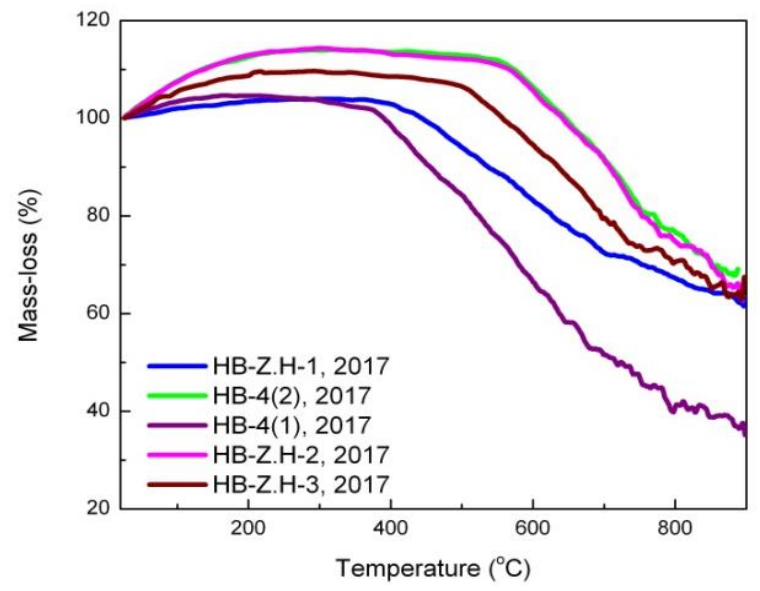

bricks HB2-3 and HB4-2. Above this temperature montmorillonite dehydroxylates and produces spinel and/or other new minerals phases such as anorthite and mullite [12], which are expected in the analysed samples. The presence of Ca-silicates with peaks at 1131 and $920 \mathrm{~cm}^{-1}$ were anorthite [5]; these are formed from the de-carbonated calcite with fired clay and quartz, respectively, at temperature above $800-850^{\circ} \mathrm{C}$. Therefore, for the red brown colored bricks HB2-1, HB2-2 and HB4-1, it suggests that the firing temperature inferred by FTIR probably in the range above $900^{\circ} \mathrm{C}$.

\section{TGA results}

Thermal analysis is an efficient way of monitoring the mass change versus the increasing temperature. Thermal analysis curves (TGA and DTA) are shown in Fig.3.

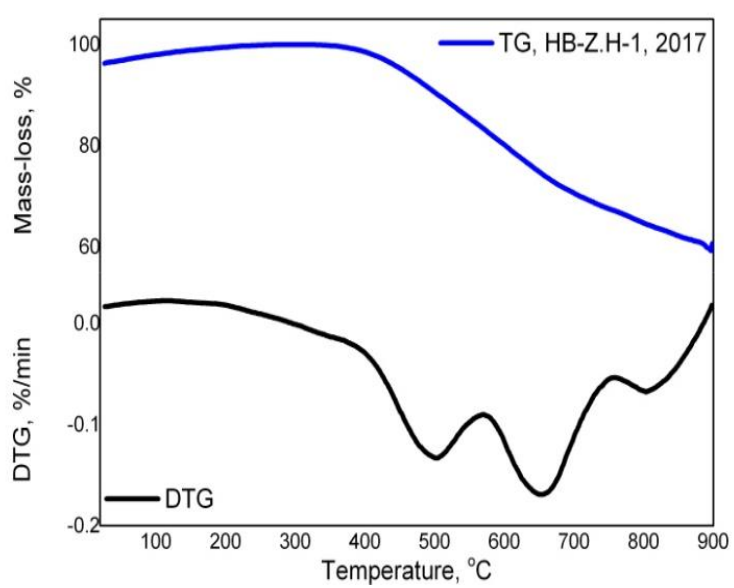

Figure 3. A). Representative thermal analysis curves of five brick samples. B) DTG curve presentation for sample $\mathrm{HB} 2-1$

According to the thermo-gravimetric approach, the mass loss, due to the thermal process, was determined considering that exothermic reactions occur at temperatures higher than that of the first heating. The thermal transformation from clay to fired ceramics includes: the dehydration of the physically absorbed and interlayer water from the clay, which takes place at $100-250^{\circ} \mathrm{C}$ [14] or at 100 $350^{\circ} \mathrm{C}$ [26] followed by the dehydroxylation, i.e. exclusion of struc-tural hydroxyls, that occurs usually at higher temperatures. The range between $700-900^{\circ} \mathrm{C}$ is characterized by the decomposition of carbonates, which starts at $650^{\circ} \mathrm{C}$ and ends at around $800-850^{\circ} \mathrm{C}$. At 900 $1100^{\circ} \mathrm{C}$, the crystalline lattice of clay minerals is destroyed and new phas-es such gehlenite, diopside, anorthite and hematite are formed.

According to Figure $3 \mathrm{~b}$, DTA curve shows three endothermic peaks at 500, 650 and $800^{\circ} \mathrm{C}$. The endothermic peak at $500^{\circ} \mathrm{C}$ corresponds to the dehydroxylation, at $650^{\circ} \mathrm{C}$ dehy-droxylation of montmorillonite and $800^{\circ} \mathrm{C}$, it can be attributed to the decomposition of calcite.

Only for sample $\mathrm{HB} 4-2$, the most important mass-loss occurs around $600^{\circ} \mathrm{C}$, therefore it is assumed that the probable firing temperature is around $600^{\circ} \mathrm{C}$. For all other samples HB2-1, HB2-2, HB2-3 and HB4-1, the mass-loss starts at temperatures above $900^{\circ} \mathrm{C}$, suggesting that the firing reached temperatures over and above $900^{\circ} \mathrm{C}$. 


\section{CONCLUSIONS}

The multi-method approach used in the archaeometric study of the ancient clay brick samples from two different sites at Karabalgasun made it possible to evaluate the composition and estimate the firing conditions of bricks. The obtained FTIR spectra were representative of two different groups; it allows the determination of clay and provides the firing temperature estimation based on the analysis of $\mathrm{Si}-\mathrm{O}$ peak position. TGA confirmed that the firing temperatures are above $900^{\circ} \mathrm{C}$, except for the sample HB4-2.

A further study of raw material fired under controlled laboratory conditions and analyzed using multi-spectroscopic analysis

\section{REFERENCES}

1. Tite, M.S., Ceramic production, provenance and use-a review*. Archaeometry, 2008. 50(2): pp. 216-231.

2. Hüttel, H.G. and U. Erdenebat, Karabalgasun and Karakorum. Two late nomadic urban settlements in the Orkhon Valley, Ulaanbaatar. 2011.

3. Pollard, A.M. and C. Heron, Archaeological Chemistry. 2008, cambridge uk: RSC publishing.

4. Artioli, G., Scientific Methods and Cultural Heritage: An introduction to the application of materials science to archaeometry and conservation science. 2010: Oxford University Press.

5. De Benedetto, G.E.L., R. Sabbatini, L. Zambonin, P. G., Infrared spectroscopy in the mineralogical characterization of ancient pottery. Journal of Cultural Heritage, 2002. 3(3): pp. 177-186.

6. Madejová, J., FTIR techniques in clay mineral studies. Vibrational Spectroscopy, 2003. 31(1): pp. 1-10.

7. Saran S., T.S., Nyamdorj D., Enkhbat G., and Turbat Ts., Analysis of the lacquer cup excavated in Tamir Valley (Arkhangai, Mongolia). Theory and praxis of archaeological research, 2019.

8. Tite, M.S., Firing temperature determinations how and why? , in The Aim of Laboratory Analyses of Ceramics in Archaeology, A.a.S. In Lindahl, O. (eds.), Editor. 1995 Kungl. including XRD, FTIR and SEM-EDX would be necessary.

In addition, the knowledge of the clay, mineral composition and firing temperature can be of value in other scientific investigations of ancient ceramics and kilns, such as thermoluminescence, RHX and magnetic dating.

\section{Acknowledgements}

Saran Solongo gratefully acknowledges TWAS research grant RGA No:17-521RG/ PHYS/AS G. The authors thank the reviewers for their valuable comments and suggestions that significantly improved the earlier version of the manuscript.

Vitterhets Historie och Antikvitets Akademien: Stockholm:. pp. 37-42.

9. Radloff, W., Atlas Drevnosstej Mongolii., ed. T. Akademii:. 1892, St. Peterburg.

10. Franken, Karabalgasun und Karakorum, Mongolei. E-Forschungsberichte, 2014: pp. 93-99.

11. Shoval, S. and P. Beck, Thermo-FTIR spectroscopy analysis as a method of characterizing ancient ceramic technology. Journal of Thermal Analysis and Calorimetry, 2005. 82(3): pp. 609-616.

12. Maritan L., et al., The provenance and production technology of bronze age and iron age pottery from Tell Mishrifeh/Qatna (Syria). Archaeometry, 2005. 47(4): pp. 723-744.

13. Drebushchak, V.A., L.N. Mylnikova, and V.I. Molodin, Thermogravimetric investigation of ancient ceramics. Journal of Thermal Analysis and Calorimetry, 2007. 90(1): pp. 73-79.

14. Drebushchak, V.A., L.N. Mylnikova, and T.N. Drebushchak, The mass-loss diagram for the ancient ceramics. Journal of Thermal Analysis and Calorimetry, 2011. 104(2): pp. 459-466.

15. Felicissimo, M.P., J.L. Peixoto, and C. Bittencourt, SEM, EPR and ToF-SIMS analyses applied to unravel the technology employed for pottery-making by pre-colonial Indian tribes from Pantanal, Brazil. Conference Proceedings, 2010.

16. Solongo, S., et al., OSL and TL characteristics of fine grain quartz from Mongolian prehistoric 
pottery used for dating. Geochronometria, 2014. 41(1): pp. 15-23.

17. Solongo, S., G.A. Wagner, and G. T, The chronology of the brick manufacturing at Karakorum, Mongolia. Preprints of the IPT, 2006. 33: pp. 60-64.

18. Saran, S., S. Tengis, and B. Tsogtbaatar, What the bricks tell us from a temple at Burkhan Khaldun mountains: Chronological insights from pIRIR luminescence. Proceedings of the Mongolian Academy of Sciences, 2016. 4: pp. 4-12.

19. Sanjurjo-Sánchez, J., J.L. Montero Fenollós, and G.S. Polymeris, Technological aspects of Mesopotamian Uruk pottery: estimating firing temperatures using mineralogical methods, thermal analysis and luminescence techniques. Archaeological and Anthropological Sciences, 2016.

20. Saran, S., S. Tengis, and B. Orgil, RHX dating of archaeological pottery: preliminary results. Preprints of the Institute of Physics and Technology, 2016. 43: pp. 143-149.

21. Müller, C.M., et al., Infrared Attenuated Total Reflectance Spectroscopy: An Innovative
Strategy for Analyzing Mineral Components in Energy Relevant Systems. Scientific Reports, 2014. 4(1): p. 6764.

22. Ravisankar R. and Senthilkumar G., Mineral analysis of coastal sediment samples of Tuna, Gujarat, India. Indian J. Sci. Technol, 2010. 3(7): pp. 774-780.

23. Maggetti, M., C. Neururer, and D. Ramseyer, Temperature evolution inside a pot during experimental surface (bonfire) firing. Applied Clay Science, 2011. 53(3): pp. 500-508.

24. Fabbri, B., S. Gualtieri, and S. Shoval, The presence of calcite in archeological ceramics, J. Eur. Ceram. Soc., 2014. 34(7): pp. 18991911.

25. Shoval, S., E. Yadin, and G. Panczer, Analysis of thermal phases in calcareous Iron Age pottery using FT-IR and Raman spectroscopy. Journal of Thermal Analysis and Calorimetry, 2011. 104(2): pp. 515-525.

26. Shoval, S. and Y. Paz, A study of the mass-gain of ancient pottery in relation to archeological ages using thermal analysis. Applied Clay Science, 2013. 82: pp. 113-120. 